\title{
The Study Effects of Dental Composite Resin as Antibacterial Agent Which Contain Nanoparticles of Zinc Oxide on the Bacteria Associated with Oral Infection
}

\author{
Reham M. Al-Mosawi ${ }^{1}$,Rafid M. Al-Badr ${ }^{2}$ \\ ${ }^{1,2}$ Dentistry College, Basrah University, Basrah, Iraq
}

\begin{abstract}
The absent of antimicrobial properties in composite resin was partly ascribed to the recurrent caries therefore the resin composite plus antimicrobial activity be useful to prevention of the secondary caries which frequently are seen around the restorations. Aim of the present study is evaluating the effectiveness of $\mathrm{ZnO}$ nanoparticles incorporating into composite resin as antimicrobial agent against bacteria causing dental caries in oral cavity.

This study examined the antibacterial effects of the nanoparticles zinc oxide as inorganic antibacterial agent on pathogenic bacteria associated with oral infectious disease, in which the bactericide of ZnO/NPs was immobilized. The antibacterial effects of inorganic antibacterial agent were assessed by employed the agar discdiffusion test, with three different concentration of prepared ZnO/NPs (in vitro) on the bacteria causing caries in this study after isolation and biochemical detection, the results show $85 \%$ reduction in growth of different kinds of bacteria which tested under study. The antibacterial agent (ZnO/NPs) exhibited strong antibacterial activity against broad-spectrum of pathogenic bacteria in oral cavity associated with caries.
\end{abstract}

Keywords: antimicrobialagents; nanomaterials; dental composites; ZnOnano particles.

\section{I . Introduction}

Dental caries is an infectious microbial disease of the teeth that results in localized dissolution and destruction of the teeth calcified tissues which caused by plaque biofilm bacteria (dental plaque), as a byproduct of their metabolism of fermentable carbohydrates /mono-sugars, then diffuse in to dental hard tissues and dissolve their mineral contents. Also the dental plaque leads to localized demineralization of tooth surfaces, which may ultimately result in formation of cavity in the tooth [1-5].

It is believed, that the dental caries is generally an infectious disease of microbial origin and was caused by multiple or all species of oral bacteria $[4,5]$. Therefore, it is reasonable to prevent and control these diseases by applying materials that are capable of killing or inactivating the causative agents of bacteria. The development of materials with antibacterial effect has long been the goal of medical science and used of resin composites for the restoration of decayed teeth, several attempts have been reported about modification of the filler or resin matrix phase to provide antibacterial effects [3, 6-12]. Thematerials Composite resin are widely used in the dental clinic for replacement of hard tissues [13, 14]. Several reports have demonstrate the experiments in which an antibacterial agents were incorporated into filling materials, in order to inhibit the microbial attachment and dental plaque accumulation on their surfaces [13-15]. However, the antibacterial effects of these materials is dependent upon, release of the agent timer and its effectiveness also this is associated with some disadvantages including toxic effects, influencing on mechanical properties, loss of effectiveness, and disruption of bacterial homeostasis $[15,16]$.

Antibacterial agents can be divided into two categories: inorganic and organic agents according to their chemical composition. Among the inorganic antibacterial agents were incorporated into resin filler materials containing silver are representatives, for a long time, but, discoloration caused by the reduction of silver ions to metallic silver has been considered a common problem for antibacterial agents which containing silver ions [11, 17-20]. Recently, certain new types of non-silver-containing inorganic antibacterial agents, basic magnesium hypochlorite, Zinc oxide whisker ( $\mathrm{ZnOw}$ ) and Zinc oxide nanoparticles ( $\mathrm{ZnO} / \mathrm{NPs})$, have been introduced, which theoretically will not cause discoloration, non-toxic, and compatible with skin, making it a suitable additive for textiles and surfaces that come in contact with humans. In addition, several modified silvercontaining agents or materials have also been reported with improved color stability [14, 21-26].

The aim of this study is evaluating the effectiveness of $\mathrm{ZnO} / \mathrm{NPs}$ incorporating into resin composites as antimicrobial agent against bacteria causing dental caries in oral cavitywith examine their physical and mechanical properties. 


\section{II . Experimental/Materials \& Methods}

The compositions of the composites used in this study are given in Table 1.

Table 1: Compositions of the composites used (\%w/w).

\begin{tabular}{|l|c|c|c|c|}
\hline & Control & $5 \%$ & $7 \%$ & $10 \%$ \\
\hline Bis-GMA $/$ TEGDMA $^{\mathrm{b}}$ & 24 & 24 & 24 & 24 \\
\hline $\begin{array}{l}\text { filler : Barium } \\
\begin{array}{l}\text { aluminosilicate } \\
\text { glass }^{c}\end{array}\end{array}$ & 76 & 71 & 69 & 66 \\
\hline $\mathrm{ZnO}$ & - & $5 \%$ & $7 \%$ & $10 \%$ \\
\hline $\mathrm{CQ}^{\mathrm{d}}$ & 0.05 & 0.05 & 0.05 & 0.05 \\
\hline Amin & 0.05 & 0.05 & 0.05 & 0.05 \\
\hline
\end{tabular}

a 2,2-bis[4-(3-methacryloxy-2-hydroxypropoxy) phenyl] propane.

${ }^{\mathrm{b}}$ Triethyleneglycoldimethacrylate.

${ }^{c}$ Barium aluminosilicate glass of particle diameter $<1.34 \mu \mathrm{m}$

${ }^{\mathrm{d}}$ Camphorquinone.

\subsection{Filler}

Barium aluminosilicate glass particles with a meanof particle diameter $<1.34 \mu \mathrm{m}$ was used after modification of surface, the silanized with $1.0 \%$ (wt $\%$ ) of $\gamma \mathrm{MPS}$.

$\mathrm{ZnO} / \mathrm{NPs}$ (average particle size of $20 \mathrm{~nm}$ with hexagonal crystal structure and $99.8 \%$ purity) (NanoparsEspadana, Isfahan, Iran) used without modification.

\subsection{Preparation of test samples}

The experimental specimens were prepared by mixture of $70 \mathrm{wt} \%$ Bis-GMA and $30 \mathrm{wt} \%$ TEGDMA was prepared as matrix phase. $0.5 \mathrm{wt} . \%$ Camphorquinone and $0.5 \% \mathrm{wt} . \mathrm{N}, \mathrm{N}$-dimethyl aminoethyl methacrylate, the silanized filler and unsilanizedZnO/NPs was then added to the matrix in different percentages $(5 \%, 7 \%$ and $10 \%$ wt).

The composite resins were inserted into a stainless-steels mold with a cylindrical cavity of $1 \mathrm{~mm}$ height and $6 \mathrm{~mm}$ diameter while the top of the mold were covered with glass. The specimens were irradiated 40 secs with a LED light source (Woodpecker china) with intensity $600 \mathrm{~W} / \mathrm{m}^{2}$ with exit window diameter of $6 \mathrm{~mm}$, the curing tip placed $1 \mathrm{~mm}$ from the glass plate.

\subsection{Anti-bacterialtest}

\subsubsection{Materials}

The microbial media used in this study are nutrient broth, Mueller-Hilton, MacConkey, mannitol salt , blood base and Nutrient agar were all, obtained from LAB of Microbiology in dentistry College within fundamental science Department in Governorate of Basrah.

\subsection{Isolation and characterization of bacteria}

In randomly form the extracted teeth were obtained from fifty (50) patients (comprising male and female in equal number) attending to the Outpatient Clinic in dentistry College for treatment of dental caries in Dental Clinic in Basrah.

Each specimen was separately collected in normal saline (sterile) after that inoculation in sterile nutrient broth for $24 \mathrm{hrs}$. then the samples were streaked onto the surfaces of prepared sterile media which were mannitol salt, MacConkey, blood base and finally on Mueller-Hilton agar media for susceptibility testing of synthesis $\mathrm{ZnO} / \mathrm{NPs}$ antimicrobial agent. At the end the identification and characterization of microbial isolates were done by the applied of conventional biochemical tests which include primitive and confirmative testing that consisting of Gram stain, IMVC test, catalase, coagulase, oxidase \& urease test [27-29].

\subsection{Antibacterial Testing}

To investigate the property of inorganic antimicrobial agent $\mathrm{ZnO} / \mathrm{NPs}$ incorporating into dental resin composites after being cured, against bacteria causing dental caries in human oral cavity. That done by employed the test of disc-diffusion agar, in this test the sterile plates are inoculation with oral microbes or bacteria after identification and characterization in present study then the synthesis materials have been placed on the sterile agar plates. Through, disc-diffusion method, bacterial isolates were inoculated to be tested by homogenous streaking (aseptically transfer inoculum) across the sterile agar plate by sterile wire loop, then incubated at $37^{\circ} \mathrm{C}$ for $24 \mathrm{~h}$. to read the inhibition results. within this test, the growth of bacterial inhibited are seen by the zones where are produced around the synthesis material which we tested, that meaning (+ve) results[30]. 


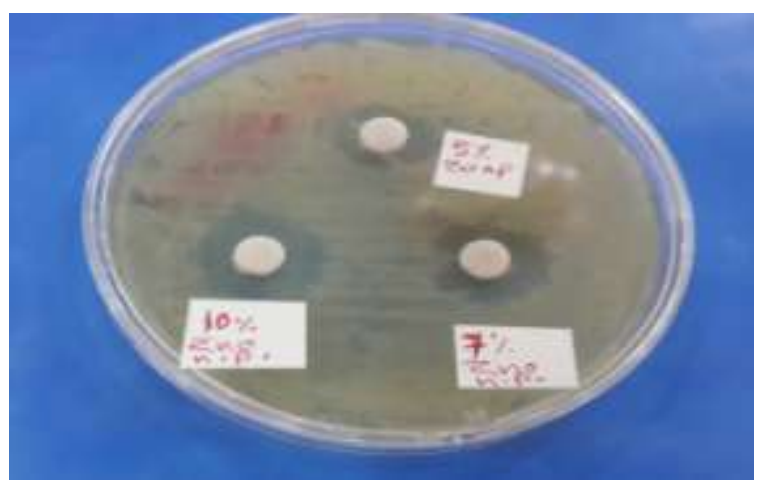

Fig. 1 : Show the susceptibility (inhibition growth) of Streptococcus mutans to the synthesis $\mathrm{ZnO} / \mathrm{NPs}$ dental composite in three concentrations 5\%,7\% and 10\% prepard from this inorganic agent.

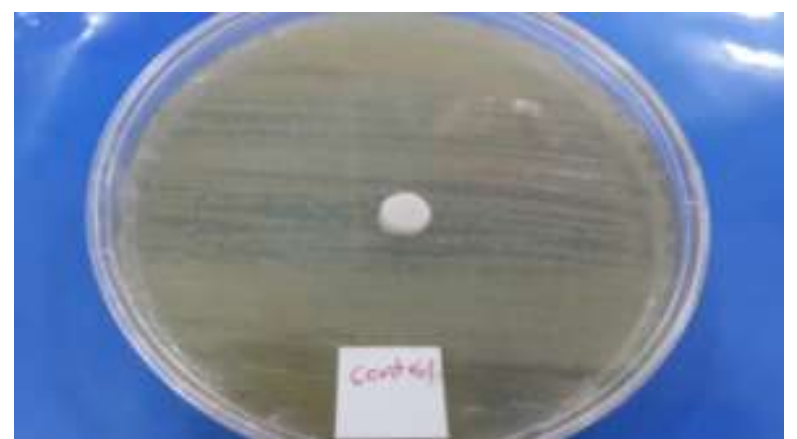

Fig. 2: Show no effect of the control (dental composite without the addition of $\mathrm{ZnO} / \mathrm{NPs}$ ) on the bacterial growth.

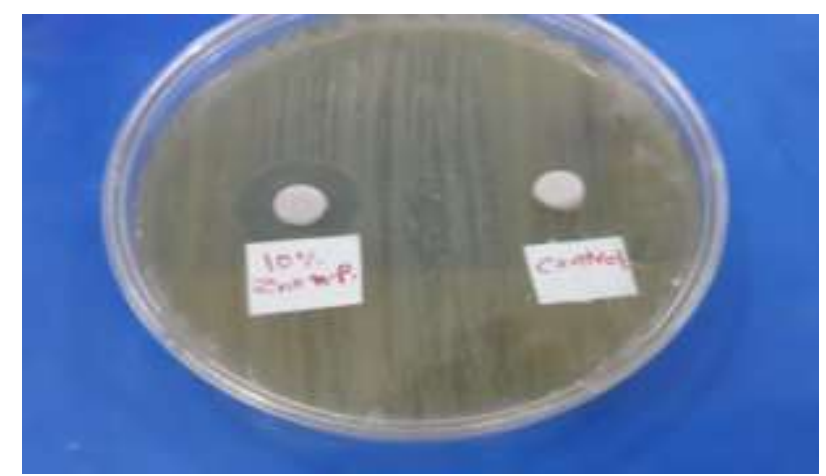

Fig. 3: Show the differences between the effect of control (dental composite resin without $\mathrm{ZnO} / \mathrm{NPs}$ ) and dental composite resin with addition of $10 \% \mathrm{ZnO} / \mathrm{NPs}$; (A) no inhibition growth of Klebsiella.spp (unsusceptible) to control , (B) inhibition growth of Klebsiella.spp (susceptible) to synthesis ZnO/NPs dental composite.

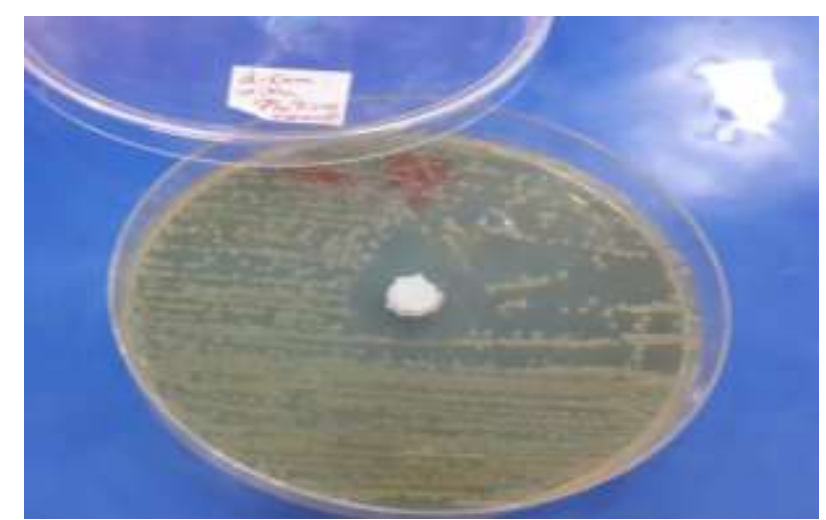

Fig. 4: Show the susceptibility (inhibition growth) of Staphylococcus aureus to the synthesis ZnO/NPs dental composite in $7 \%$ concentration prepard from this inorganic agent. 


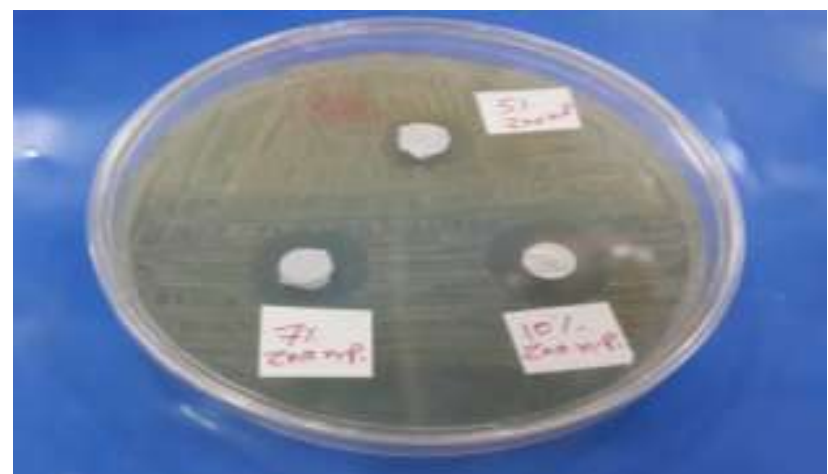

Fig. 5: Show the susceptibility (inhibition growth) of Pseudomonas areuginosa to the synthesis $\mathrm{ZnO} / \mathrm{NPs}$ dental composite in three concentrations $5 \%, 7 \%$ and $10 \%$ prepard from this inorganic agent.

\section{III . Results}

Table 2: Number of positive bacterial culture from specimens correlated with sex.

\begin{tabular}{|l|c|c|}
\hline Sex & No. of specimen & No. of (+ve) bacterial culture \\
\hline Male & 25 & 11 \\
\hline Female & 25 & 15 \\
\hline Total & 50 & 26 \\
\hline
\end{tabular}

In our study Table (2), represents the (26) isolates of bacteria from all caries specimens (50) showed the results, positive from culturing of bacteria in these specimens in which the male and female patients are respectively positive.

Table3: Distribution the species of bacterial isolates in patient's caries according to gender.

\begin{tabular}{|c|c|c|c|c|c|}
\hline \multicolumn{6}{|c|}{ No. and $(\%)$ of bacterial isolates } \\
\hline $\begin{array}{l}\overrightarrow{\bar{v}} \\
\bar{v} \\
\bar{v}\end{array}$ & 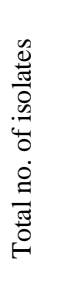 & 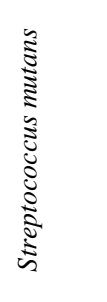 & 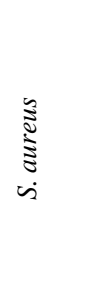 & 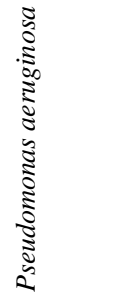 & 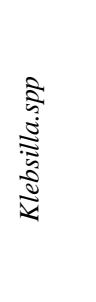 \\
\hline Male & 11 & $5(45.45)$ & $3(27.27)$ & $2(18.18)$ & 1(9.09) \\
\hline Female & 15 & $7(46.66)$ & $4(26.66)$ & $3(20)$ & $1(6.66)$ \\
\hline
\end{tabular}

Table (3), shows the association of the positive number + ve number of bacterial isolates in patients caries from male and female under study with percentage of each bacteria, in our study isolated four types of bacteria they consisted of Streptococcus.spp which was the most frequently isolated bacterial species $45.45 \%, 46.66 \%$ followed by Staphylococcus aureus $27.27 \%$, $26.66 \%$; Pseudomonas areuginosa $18.18 \%, 20 \%$ and Klebsiella.spp $9.09 \%, 6.66 \%$ in all cases with percentage ratio respectively in male and female.

Table 4: Antibacterial activity of the synthesis $\mathrm{ZnO} / \mathrm{NPs}$ dental composite against bacterial isolates from cases of dental caries.

\begin{tabular}{|c|c|c|c|c|}
\hline \multicolumn{5}{|c|}{ No.(+ve) of bacterial isolates with diameter of inhibition zone $(\mathrm{mm})$} \\
\hline $\begin{array}{l}\text { Concentration of synthesis ( } \mathrm{ZnO} / \mathrm{NPs}) \\
\text { dental composite }\end{array}$ & 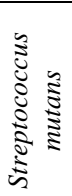 & $\begin{array}{c}\tilde{\Xi} \\
\stackrel{\Xi}{\Xi} \\
\dot{\Xi} \\
\dot{\vdots}\end{array}$ & 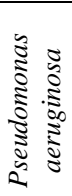 & 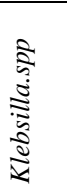 \\
\hline $5 \%$ & 9 & 5 & 11 & 8 \\
\hline $7 \%$ & 15 & 11 & 13 & 11 \\
\hline $10 \%$ & 17 & 10 & 15 & 13 \\
\hline
\end{tabular}

Antibacterial susceptibility profiles Table (4) reveal that the synthesis $\mathrm{ZnO} / \mathrm{NPs}$ dental composite in different concentrations $(5 \%, 7 \%, 10 \% \mathrm{wt})$ displayed the activity against all isolated of bacterial species. The 
most susceptible of bacterial isolates were Streptococcus.sppand Pseudomonas areuginosa with inhibition zones correspond to $17 \mathrm{~mm}, 15 \mathrm{~mm}$ in concentration $10 \%$ of synthesis ZnO/NPs dental composite; $15 \mathrm{~mm}, 13 \mathrm{~mm}$ in concentration $7 \%$ of synthesis $\mathrm{ZnO} / \mathrm{NPs}$ dental composite and $9 \mathrm{~mm}, 11 \mathrm{~mm}$ in concentration $5 \%$ of synthesis $\mathrm{ZnO} / \mathrm{NPs}$ dental composite followed by other types of bacteria, the growth of Staphylococcus aureus and Klebsiella.spp were inhibited by synthesis $\mathrm{ZnO} / \mathrm{NPs}$ dental composite with inhibition zones correspond to $(10 \mathrm{~mm}, 13 \mathrm{~mm})$ in concentration $10 \%$ while in concentration $7 \%$ of synthesis $\mathrm{ZnO} / \mathrm{NPs}$ were corresponding to $11 \mathrm{~mm}$ for each types of bacteria and in $5 \%$ concentration of synthesis dental composite were $5 \mathrm{~mm}, 8 \mathrm{~mm}$ respectively.

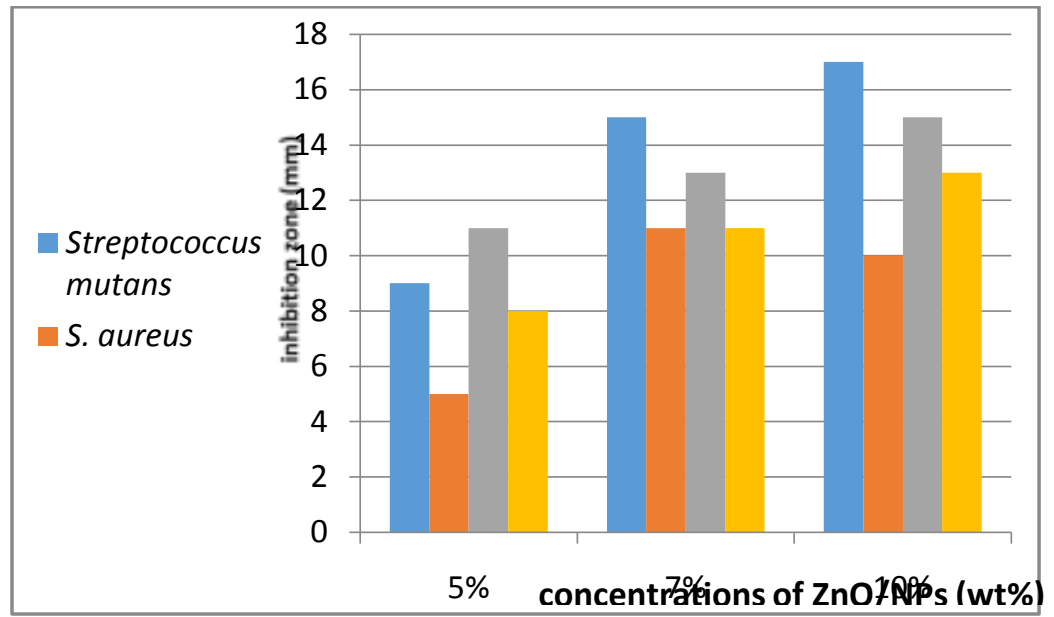

Fig. 6: The positive number of bacterial isolates with susceptibility (inhibition zone $\mathrm{mm}$ ) to synthesis $\mathrm{ZnO} / \mathrm{NPs}$ dental composite.

Also, in our study we tested the antimicrobial susceptibility of modified synthesis $\mathrm{ZnO} / \mathrm{NPs}$ dental composite on bacterial isolates from patient's caries, revealed that no effects against all isolated of bacterial species in different concentrations.

\section{IV . Discussion}

Nanotechnology is a molecular-level technology and making progress in several scientific fields, with promising scientific and applied field in today's medicine, including dentistry. In this technology, the materials are converted into Nano metric sizes in order to produce a new Properties for these materials [31, 32]. Nanoparticles possess unique physic-chemical, biological and optical properties in which can be manipulated for suitable desired applications [33]. Zinc oxide and silver successfully used in biological and chemical sensors, bactericidal agents, electronics and photo electronic devices and have considerable bio-activity as well [34-36]. $\mathrm{ZnO} / \mathrm{NPs}$ have exhibited a strong bacterial growth inhibiting character [22]. Zinc oxide and silver have proper antimicrobial activity and when they are converted into nanoparticles increasing their surface to volume ratio with improving their antibacterial activity [37, 38]. the current study made an attempt to evaluation the antibacterial properties of composite resins containing zinc oxide nanoparticles against Streptococcus mutans, Pseudomonas areuginosa, Staphylococcus aureus and Klebsiella.spp (some species of gram positive and gram negative bacteria), which have a significant role in recurrentcaries . Zinc oxide is a safe bactericidal metallic oxide (inorganic agent) because it isnon-toxic to animal cells in low concentrations but is very toxic to bacteria, killing them, although, the metals and metallic oxides as zinc oxide, are considered toxic to human cells at highconcentrations, they do not seem to be toxic at very low concentrations on human cells[32, 39-41]. In present study that was conducted on (50) caries samples , 26 isolates of bacteria from all caries specimens showed positive results due to bacterial culturing of these samples which are positive for male and female patients respectively as seen in Table 2, anyhow, our results were consistent with workers [42] observation . in our study isolated four types of bacteria they consisted of Streptococcus mutans which was the most frequently isolated bacterial species $(45.45 \%, 46.66 \%)$ followed by Staphylococcus aureus $(27.27 \%, 26.66 \%)$; Pseudomonas areuginosa $(18.18 \%, 20 \%)$ and Klebsiella.spp $(9.09 \%, 6.66 \%)$ in all cases with percentage ratio respectively in male and female Table 3.

The findings of BB Oluremiet.al[42] were, to some extent, in agreement with the results of current study . Table 4 and figure 6 profiles, the antibacterial susceptibility of the synthesis $\mathrm{Zno} / \mathrm{Nps}$ dental composite in different concentrations $(5 \%, 7 \%, 10 \% \mathrm{wt})$ which displayed that the activity against all isolated of bacterial species. The most susceptible of bacterial isolates were Streptococcus mutans and Pseudomonas areuginosa with inhibition zones correspond to $15 \mathrm{~mm}, 17 \mathrm{~mm}$ in concentration $10 \%$ of synthesis ZnO/NPs dental 
composite in our study these results suggest that, the synthesis $\mathrm{ZnO} / \mathrm{NPs}$ dental composite may play a vital role in the prevention of dental caries since Streptococcus mutans has been implicated in the initiation of caries $13 \mathrm{~mm}, 15 \mathrm{~mm}$ in concentration $7 \%$ of synthesis $\mathrm{ZnO} / \mathrm{NPs}$ dental composite and $9 \mathrm{~mm}, 11 \mathrm{~mm}$ in concentration $5 \%$ of synthesis $\mathrm{ZnO} / \mathrm{NPs}$ dental composite followed by other types of bacteria, the growth of Staphylococcus aureus and Klebsiella.spp were inhibited by synthesis $\mathrm{ZnO} / \mathrm{NPs}$ dental composite with inhibition zones correspond to $10 \mathrm{~mm}, 13 \mathrm{~mm} ; 11 \mathrm{~mm}, 11 \mathrm{~mm}, 5 \mathrm{~mm}$, and $8 \mathrm{~mm}$ in concentrations of $10 \%, 7 \%$ and $5 \%$ wt respectively. Our results were consistent with Berdan Aydin Sevinc\& Luke Hanley [23] results . In some studies , the technique of diffusion agar disc has been used for evaluation of antibacterial properties of cured composite resin $[14,23]$, as in current study, used the disc-diffusion method, in which the bacterial isolates were inoculated to be tested by homogenous streaking (aseptically transfer inoculum) across the sterile agar plate by sterile wire loop, then incubated at $37^{\circ} \mathrm{C}$ for $24 \mathrm{~h}$. to read the inhibition results . within this method, an inhibition growth zone around the material is produced mean the (+ve) results.

Also, in our study we tested the antimicrobial susceptibility of modified synthesis ZnO/NPs dental composite on bacterial isolates from patient's caries, revealed that no effects against all isolated of bacterial species in different concentrations.

\section{Conclusion}

With the limitation of current study, we may conclude that, the antibacterial susceptibility of the synthesisZnO/NPs dental composite in different concentrations $(5 \%, 7 \%, 10 \%)$ which displayed that the activity against all isolated of bacterial species; the most susceptible of bacterial isolates were Streptococcus mutans and Pseudomonas areuginosa, in our study these results suggest that, the synthesis $\mathrm{ZnO} / \mathrm{NPs}$ dental composite may play a vital role in the prevention of dental caries since Streptococcus mutans has been implicated in the initiation of caries.

The antimicrobial susceptibility of modified synthesis $\mathrm{ZnO} / \mathrm{NPs}$ dental composite tested on bacterial isolates from patient's caries and revealed that no effects against all isolated of bacterial species in different concentrations.

\section{References}

[1]. Pereira-Cenci, T., et al., Antibacterial agents in composite restorations for the prevention of dental caries. Cochrane Database Syst Rev. 12:2013 p.

[2]. SKJöRLAND, K.K., Plaque accumulation on different dental filling materials. European Journal of Oral Sciences. 81(7):1973 p. 538-542.

[3]. Syafiuddin, T., et al., In vitro inhibition of caries around a resin composite restoration containing antibacterial filler. Biomaterials. 18(15): 1997 p. 1051-1057.

[4]. Van Houte, J., Role of micro-organisms in caries etiology. Journal of dental research. 73(3):1994 p. 672-681.

[5]. Cummins, D., Zinc citrate/Triclosan: a new anti-plaque system for the control of plaque and the prevention of gingivitis: short-term clinical and mode of action studies. Journal of clinical periodontology. 18(6):1991 p. 455-461.

[6]. Bapna, M., R. Murphy, and S. Mukherjee, Inhibition of bacterial colonization by antimicrobial agents incorporated into dental resins. Journal of oral rehabilitation. 15(5):1988 p. 405-411.

[7]. Imazato, S., et al., Antibacterial activity of bactericide-immobilized filler for resin-based restoratives. Biomaterials. 24(20):2003 p. 3605-3609.

[8]. Kim, S., et al., Inhibition of Streptococcus mutans biofilm formation on composite resins containing ursolic acid. Restorative dentistry \& endodontics. 38(2):2013 p. 65-72.

[9]. Wilson, N.H., F. Burke, and I.A. Mjör, Reasons for placement and replacement of restorations of direct restorative materials by a selected group of practitioners in the United Kingdom. Quintessence International. 28(4):1997 p.

[10]. Tanagawa, M., et al., Inhibitory effect of antibacterial resin composite against Streptococcus mutans. Caries research. 33(5):1999 p. 366-371.

[11]. Yoshida, K., M. Tanagawa, and M. Atsuta, Characterization and inhibitory effect of antibacterial dental resin composites incorporating silver-supported materials. Journal of biomedical materials research. 47(4):1999 p. 516-522.

[12]. Yoshida, K., et al., Antibacterial activity of resin composites with silver-containing materials. European Journal of Oral Sciences. 107(4):1999 p. 290-296.

[13]. Mjör, I.A., J.E. Moorhead, and J.E. Dahl, Selection of restorative materials in permanent teeth in general dental practice. Acta Odontologica Scandinavica. 57(5):1999 p. 257-262.

[14]. Imazato, S., Antibacterial properties of resin composites and dentin bonding systems. Dental materials. 19(6):2003 p. 449-457.

[15]. JEDRYCHOWSKI, J.R., A.A. CAPUTO, and S. KERPER, Antibacterial and mechanical properties of restorative materials combined with chlorhexidines. Journal of oral rehabilitation. 10(5):1983 p. 373-381.

[16]. Ribeiro, J. and D. Ericson, In vitro antibacterial effect of chlorhexidine added to glass-ionomer cements. European Journal of Oral Sciences. 99(6): 1991 p. 533-540.

[17]. Swanson, T. and N. Tinanoff, Antiplaque properties of sustained release SnF2: pilot studies. Journal of oral rehabilitation. 11(1):1984 p. 53-63.

[18]. Chen, J., Y. Chen, and C. Zhou, New kind of inorganic antibacterial agent: basic magnesium hypochlorite. Inorg Chem Ind. 34:2002 p. 32-3.

[19]. Fang, M., et al., Antibacterial activities of inorganic agents on six bacteria associated with oral infections by two susceptibility tests. International Journal of Antimicrobial Agents. 27(6):2006 p. 513-517.

[20]. Yamamoto, K., et al., Antibacterial activity of silver ions implanted in SiO 2 filler on oral streptococci. Dental materials. 12(4):1996 p. 227-229. 
[21]. Martinez-Gutierrez, F., et al., Synthesis, characterization, and evaluation of antimicrobial and cytotoxic effect of silver and titanium nanoparticles. Nanomedicine: Nanotechnology, Biology and Medicine. 6(5):2010 p. 681-688.

[22]. Sawai, J., Quantitative evaluation of antibacterial activities of metallic oxide powders $(\mathrm{ZnO}, \mathrm{MgO}$ and $\mathrm{CaO})$ by conductimetric assay. Journal of Microbiological Methods. 54(2):2003 p. 177-182.

[23]. Aydin Sevinç, B. and L. Hanley, Antibacterial activity of dental composites containing zinc oxide nanoparticles. Journal of Biomedical Materials Research Part B: Applied Biomaterials. 94(1):2010 p. 22-31.

[24]. Hojati, S.T., et al., Antibacterial, physical and mechanical properties of flowable resin composites containing zinc oxide nanoparticles. Dental materials. 29(5):2013 p. 495-505.

[25]. Sondi, I. and B. Salopek-Sondi, Silver nanoparticles as antimicrobial agent: a case study on E. coli as a model for Gram-negative bacteria. Journal of colloid and interface science. 275(1):2004 p. 177-182.

[26]. Kim, J.S., et al., Antimicrobial effects of silver nanoparticles. Nanomedicine: Nanotechnology, Biology and Medicine. 3(1):2007 p. 95-101.

[27]. Vos, P., et al., Bergey's Manual of Systematic Bacteriology: Volume 3: The Firmicutes. Vol. 3. 2011: Springer Science \& Business Media.

[28]. Williams, S., M. Sharpe, and J. Holt, Bergey’s manual of determinative bacteriology. Baltimore: Williams and Wilkins. Ji, GD, Sun, TH, Ni, JR, \& Tong, JJ (2009). Anaerobic baffled reactor (ABR) for treating heavy oil produced water with high concentrations of salt and poor nutrient. Biore-source Technology. 100(3):1994 p. 11081114.

[29]. Cowan, S.T., et al., Cowan and Steel's manual for the identification of medical bacteria. 2004: Cambridge university press.

[30]. Barry, A. and R. Lasner, In-vitro methods for determining minimal lethal concentrations of antimicrobial agents. American journal of clinical pathology. 71(1):1979 p. 88-92.

[31]. Sahoo, S., S. Parveen, and J. Panda, The present and future of nanotechnology in human health care. Nanomedicine: Nanotechnology, Biology and Medicine. 3(1):2007 p. 20-31.

[32]. Li, L.-H., et al., Synthesis and characterization of chitosan/ZnO nanoparticle composite membranes. Carbohydrate research. 345(8):2010 p. 994-998.

[33]. Feynman, R.P., There's Plenty of Room at the Bottom. Resonance-Heidelberg. 16(9):2011 p. 890.

[34]. Zhong, C.-J. and M.M. Maye, Core-shell assembled nanoparticles as catalysts. Advanced Materials. 13(19):2001 p. 1507-1511.

[35]. Liz-Marzán, L.M., Tailoring surface plasmons through the morphology and assembly of metal nanoparticles. Langmuir. 22(1):2006 p. 32-41.

[36]. Alammar, T. and A.-V. Mudring, Facile preparation of Ag/ZnO nanoparticles via photoreduction. Journal of materials science. 44(12):2009 p. 3218-3222.

[37]. Yamamoto, O., Influence of particle size on the antibacterial activity of zinc oxide. International Journal of Inorganic Materials. 3(7):2001 p. 643-646.

[38]. Brett, D.W., A discussion of silver as an antimicrobial agent: alleviating the confusion. Ostomy/wound management. 52(1):2006 p. 34-41.

[39]. Bundy, K., M. Butler, and R. Hochman, An investigation of the bacteriostatic properties of pure metals. Journal of biomedical materials research. 14(5):1980 p. 653-663.

[40]. Applerot, G., et al., Coating of glass with $\mathrm{ZnO}$ via ultrasonic irradiation and a study of its antibacterial properties. Applied surface science. 256(3):2009 p. S3-S8.

[41]. Li, L.-H., et al., Preparation, characterization and antimicrobial activities of chitosan/Ag/ZnO blend films. Chemical Engineering Journal. 160(1):2010 p. 378-382.

[42]. Oluremi, B., et al., Evaluation of anticaries activity of selected mouthwash marketed in Nigeria. Tropical journal of pharmaceutical research. 9(6):2010 p. 